\title{
Evaluating growth and biochemistry of Westiellopsis prolifica in response to Malathion
}

\author{
Jyotishmita Dutta* \& P P Baruah \\ Department of Botany, Gauhati University, Guwahati 781 014, Assam, India
}

\section{Article history}

Received: 31 July 2019

Accepted: 07 September 2019

Published: 06 October 2019

\section{Publisher}

Horizon e-Publishing Group

\section{*Correspondence}

Jyotishmita Dutta

$\triangle$ jyotishmitadutta90@gmail.com

\begin{abstract}
The present endeavour was aimed to investigate the chronic response of Westiellopsis prolifica to an organophosphate insecticide malathion at different concentrations 30, 60 and 90ppm. The influence of malathion on growth (biomass), pigments (chlorophyll-a, carotenoid), release of metabolites such as protein and carbohydrate was analysed for a period of 16 days under aseptic laboratory conditions. Results revealed enhancement in chlorophyll-a production at $30 \mathrm{ppm}$ on $4^{\text {th }}$ day $(p<0.05)$ and $8^{\text {th }}$ day $(p>0.05)$, from the day of inoculation. On the other hand, there was a significant decrease in the carotenoid, protein and carbohydrate content with increase in malathion concentration in a time and dose dependent manner. However, a little but insignificant increase in biomass was recorded on the $4^{\text {th }}$ day at $30 \mathrm{ppm}$ concentration over the control. The study revealed that the reduction in biomass, protein and carbohydrate content with the increase of malathion concentrations was an indication of its toxicity to the test cyanobacterium which is one of the natural biofertilizers in the rice field ecosystem.
\end{abstract}

Keywords: Cyanobacterium; Organophosphate; Malathion; Westiellopsis prolifica

Citation: Dutta J, Baruah P P. Evaluating growth and biochemistry of Westiellopsis prolifica in response to Malathion. Plant Science Today 2019;6(4):505-511. https://doi.org/10.14719/pst.2019.6.4.622

Copyright: (c) Dutta \& Baruah (2019). This is an open-access article distributed under the terms of the Creative Commons Attribution License, which permits unrestricted use, distribution, and reproduction in any medium, provided the original author and source are credited (https://creativecommons.org/licenses/by/4.0/).

Indexing: Plant Science Today is covered by Scopus, Web of Science, BIOSIS Previews, ESCI, CAS, AGRIS, CABI, Google Scholar, etc. Full list at http://www.plantsciencetoday.online

\section{Introduction}

Pesticides are synthetic organic compounds used in almost all the crop fields to control unwanted but selective pests (1). There are various types of pesticides widely used throughout the tropic which includes organophosphate, organochlorine, carbamate and pyrethroid groups. These are chemical compounds and are stimulatory, inhibitory or neutral depending on the nature of the chemicals, its concentration and the time of treatment (2). The use of pesticides has become an integral part of modern agricultural practices. Though they are being used for killing some targeted organisms, it ends up affecting the non targeted and beneficial organisms too. Thus, continuous addition of these chemicals to the rice fields affects the dynamic equilibrium of the soil environment (3) hampering the growth of beneficial soil microbes including nitrogen fixing cyanobacteria. It has been reported that 10-15\% yield loss in rice production is accounted for insect/ pest related causes (4). To overcome this loss, 
different insecticides are used throughout the globe and malathion is one of them.

According to Patil and David (5), Malathion is a non-systemic, wide spectrum organophosphate insecticide used in both agricultural and nonagricultural practices. There are reports which inform that malathion has adverse effects on a number of algal groups and cyanobacterial species $(6,7)$.

Cyanobacteria are photosynthetic prokaryotes which has the ability to grow in both terrestrial and aquatic environment. They are important in agricultural fields as they can fix nitrogen, produce growth hormones, enhance soil fertility etc. The wide distribution of cyanobacteria reflects a broad spectrum of physiological properties and their tolerance capacity to environmental stresses including pesticidal toxicity (8).

W. prolifica, is abundantly found in all agricultural fields in general and rice fields in particular (9). It is one of the dominant cyanobacterial genera in the rice field soils of India $(10,11)$. They are of great economic and ecological significance due to their ability of fixation of elementary nitrogen (12, 13). The genera was reported to increases the soil fertility with humus and nitrogen content. It is also used as a 'diazotroph biofertilizer' (14). Reports suggest that regular exposure of cyanobacteria to pesticides have some deleterious effects on them (15).

It is essential to understand factors which hampers nitrogen fixation in rice fields. Weedicides, fungicides and pesticides which are used for protection of the crops in the rice fields are reported to have adverse effect on the cyanobacterial population. Thus in the present study, the effect of a commonly used pesticide, malathion on the growth and biochemistry on a common cyanobacterial biofertilizer

$(W$. prolifica).

\section{Material and Methods}

\section{Isolation and maintenance}

The test organism, $W$. prolifica was isolated from the rice field soils of Assam. The pure cultures of the species was grown and maintained in BG-11 media without nitrogen at a temperature of $25 \pm 2$ ${ }^{\circ} \mathrm{C}$, under a light intensity of 2000-3000 lux intensity and alternating with light/dark cycles of $14 / 10$ hours.

\section{Pesticide used}

The pesticide used for the study was malathion ( $50 \% \mathrm{EC})$, an organophosphate insecticide which is commonly used in rice fields is obtained from a chemical shop in Guwahati (Assam). The molecular formula and chemical name of malathion is $\mathrm{C}_{10} \mathrm{H}_{19} \mathrm{O}_{6} \mathrm{PS}_{2}$ and $\mathrm{O}$, O-dimethyl phosphorodithioate of diethyl mercaptosuccinate. The stock solution of the pesticide was prepared by adding appropriate dilution of $50 \% \mathrm{EC}$ malathion to $1000 \mathrm{ml}$ of sterilized double distilled water. From the stock solution, a desired amount of pesticide was added aseptically to the culture tubes to get the final concentrations of $30 \mathrm{ppm}, 60 \mathrm{ppm}$ and 90ppm based on the $\mathrm{LC}_{50}$ value.

\section{$\mathrm{LC}_{50}$ value}

The test species was subjected to various concentrations from 10ppm-120ppm, from which the $\mathrm{LC}_{50}$ value was calculated in terms of chlorophyll-a (16) and recorded to be 60ppm. Based on the $\mathrm{LC}_{50}$ value, various concentrations of $30 \mathrm{ppm}$, 60ppm and 90ppm were taken along with the control (without pesticide) to do the analysis.

\section{Biomass estimation}

To estimate biomass, $20 \mathrm{ml}$ of the culture was centrifuged and filtrated. The filtered was properly washed with double distilled water for removing the adhering pesticides in the samples. The harvested wet pellet weighted around $4.5 \mathrm{mg}$. The washed material was oven dried at $80^{\circ} \mathrm{C}$ for 72 $\mathrm{hr}$. The test was done in triplicate for both treated and control sets and at an interval of 4 days (17).

\section{Chlorophyll-a estimation}

The homogenate cyanobacterial suspensions were washed with double distilled water to remove the traces of pesticides. The suspension was then homogenised with $10 \mathrm{ml}$ of $95 \%$ methanol using mortar and pestle and boiled in a water bath for 30 minutes at $65^{\circ} \mathrm{C}$ temperature. The samples were than cooled and centrifuged at $3000 \mathrm{rpm}$ for 10 minutes. The absorbance of the supernatant was read against $95 \%$ methanol as blank at $663 \mathrm{~nm}$ in a UV-Visible spectrophotometer 119 (SYSTRONICS) (18).

\section{Carotenoid estimation}

For calculating the total carotenoid, the samples were first washed with double distilled water and then suspended in $80 \%$ acetone and incubated overnight at $4^{\circ} \mathrm{C}$. Next day, the samples were centrifuged and the supernatant was read in the spectrophotometer at $480 \mathrm{~nm}$ against $80 \%$ acetone as blank (19).

\section{Protein estimation}

Algal biomass of $1 \mathrm{mg}$ was taken in a test tube and to it $1 \mathrm{ml}$ of $1 \mathrm{~N} \mathrm{NaOH}$ was added and then the tubes were kept in a boiling water bath for 10 minutes. After that, the tubes were cooled and $5 \mathrm{ml}$ of reagent $A$ was added (prepared by adding $1 \mathrm{ml}$ freshly prepared $1 \% \mathrm{Na}-\mathrm{K}$ tartarate solution in 50 $\mathrm{ml}$ of $2 \% \mathrm{Na}_{2} \mathrm{CO}_{3}$ solution containing $0.5 \% \mathrm{CuSO}_{4}$ ) and incubated at room temperature for $10 \mathrm{~min}$. This was followed by the addition of $0.5 \mathrm{ml}$ of reagent B (Folin reagent), mixed properly and incubated at room temperature for another 30 
min. The absorbance of the supernatant was read at $650 \mathrm{~nm}$ against folin reagent as blank. The amount of protein content was determined by comparing it with the standard curve of protein prepared with Bovine Serum Albumin as a standard (20).

\section{Carbohydrate estimation}

For carbohydrate estimation, $0.5 \mathrm{ml}$ of homogenised algal suspension was taken in test tube and volume was made to $1 \mathrm{ml}$ by addition of distilled water. It was followed by addition of $4 \mathrm{ml}$ anthrone reagent to the tubes (prepared by addition of $100 \mathrm{mg}$ of anthrone with 1gm thiourea in $100 \mathrm{ml}$ of $75 \%$ sulphuric acid). The tubes were then kept at boiling water bath for 10 minutes. Finally, the tubes were brought to room temperature and absorbance was read at $625 \mathrm{~nm}$. The final carbohydrate content was calculated from the standard graph prepared with glucose as standard (21).

\section{Statistical analysis}

The experiment was carried out in triplicates and was expressed as mean \pm standard deviation $(\mathrm{N}=3)$. The significant test were carried out with one way analysis of variance (ANOVA) followed by post hoc (Dunnet) test $(p<0.05$ for significant) using software Graph Pad prism 5.01.

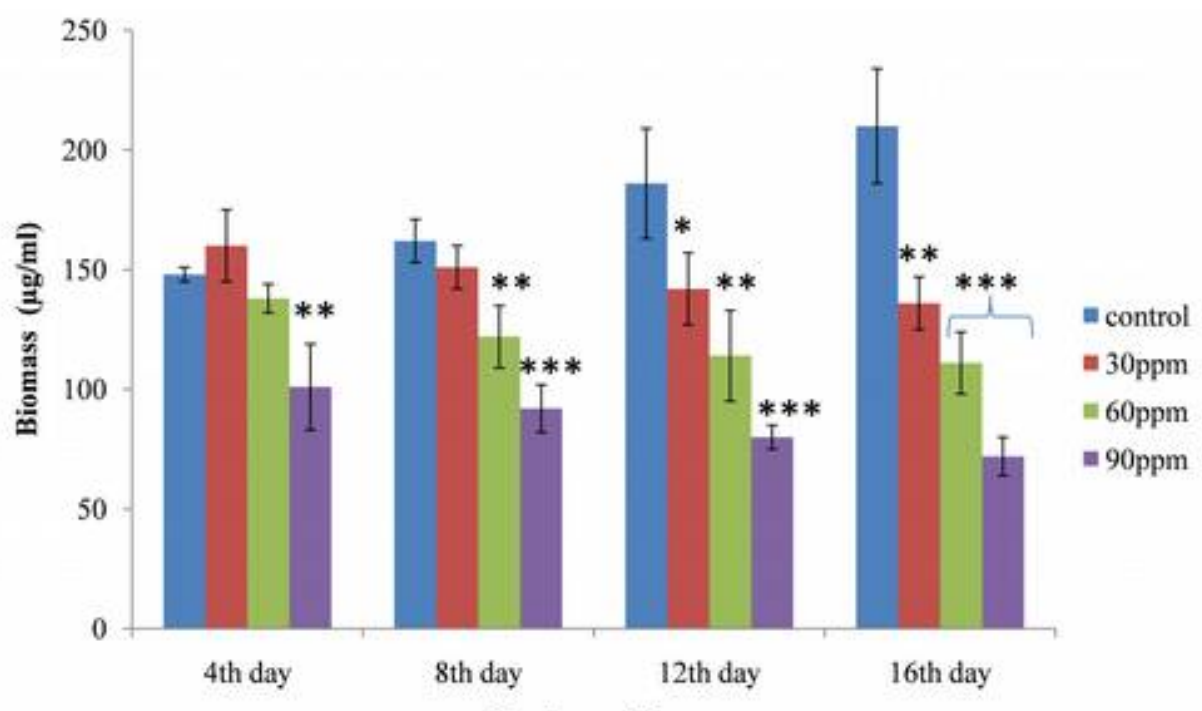

Number of days

Fig. 1. Effect of different concentrations of malathion on the biomass content of $W$. prolifica at different time intervals. The values are presented as mean \pm SD of three replicates. Asterisks $\left({ }^{*} p<0.05,{ }^{* *} p<0.01,{ }^{* * *} p<0.001\right)$ above the histogram bars depicts significant variation in the pesticides treated samples over the control.

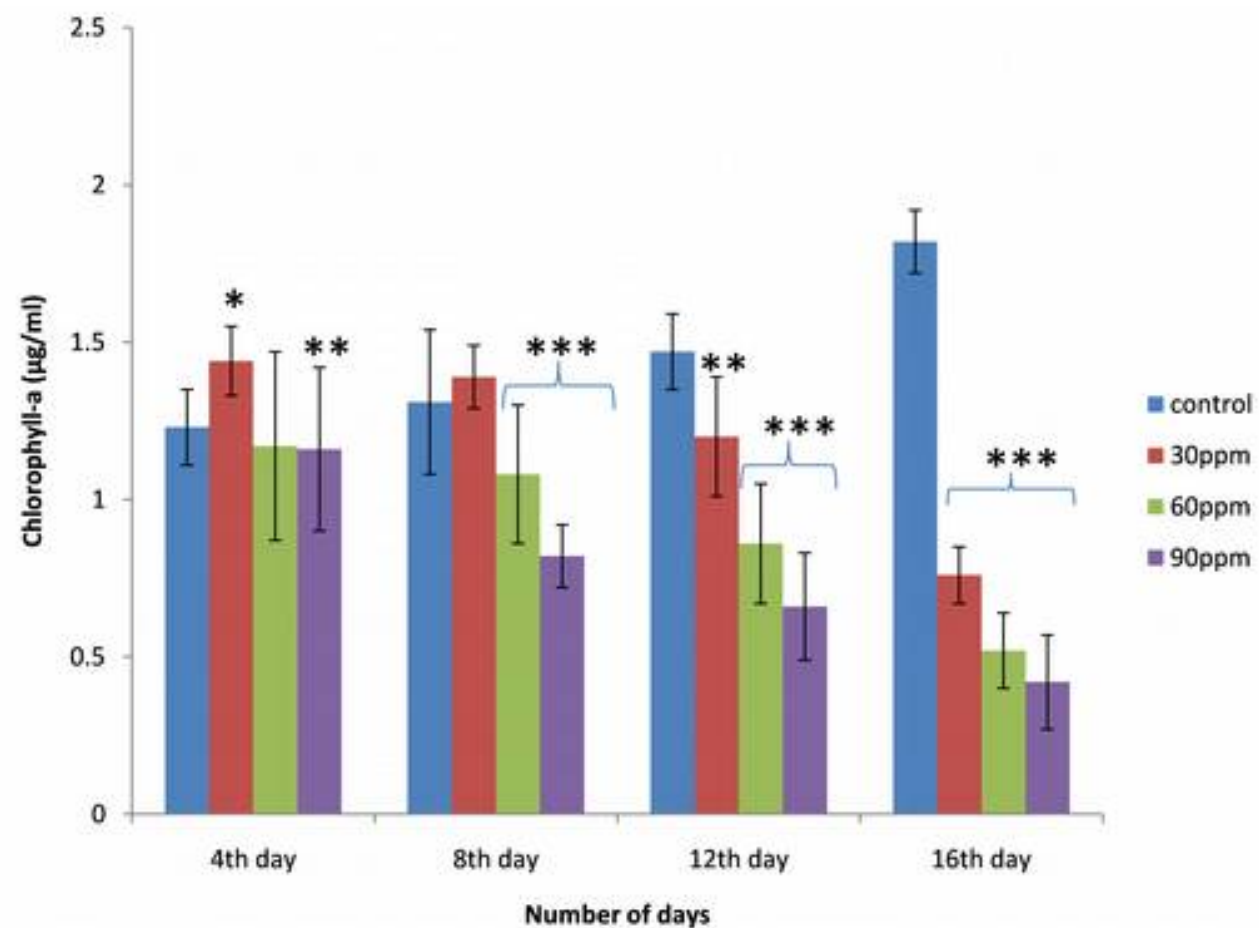

Fig. 2. Effect of different concentrations of malathion on the chlorophyll-a content of $W$. prolifica at different time intervals . The values are presented as mean \pm SD of three replicates. Asterisks $\left({ }^{*} p<0.05,{ }^{* *} p<0.01,{ }^{* * *} p<0.001\right)$ above the histogram bars depicts significant variation in the pesticides treated samples over the control. 


\section{Results}

\section{Biomass}

The biomass content of $W$. prolifica with malathion treatment is shown in the Fig. 1. From the figure, it was observed that the biomass content of the test species decreases from lower to higher concentrations up to $16^{\text {th }}$ day from the day of inoculation, over the control, but on the $4^{\text {th }}$ day, at $30 \mathrm{ppm}$ concentration there was a little but insignificant increase in the biomass content compared to the control. The growth was found to be highest in the control set on the $16^{\text {th }}$ day $(210 \pm 12) \mu \mathrm{g} / \mathrm{ml}$ and the lowest growth was observed at $90 \mathrm{ppm}$ on the $16^{\text {th }}$ day of treatment $(72 \pm 16) \mu \mathrm{g} / \mathrm{ml}(p<0.001)$.

\section{Chlorophyll-a}

The growth of the test organism in terms of Chlorophyll-a is depicted in Fig. 2. From the figure, chlorophyll-a production was found to be slightly higher than the control at $30 \mathrm{ppm}$ on the $4^{\text {th }}$ day $(p<0.05)$ and on $8^{\text {th }}$ day $(p>0.05)$ from the day of inoculation. There was a gradual reduction in chlorophyll-content from lower dose to higher dose of pesticide on the $12^{\text {th }}$ and $16^{\text {th }}$ day. The highest chlorophyll-a content was found in the untreated set that is in the control, on the $16^{\text {th }}$ day $(1.82 \pm 0.1 \mu \mathrm{g} / \mathrm{ml})$ and the highest inhibitory concentration was found to be $90 \mathrm{ppm}$ with lowest reduction of chlorophyll-a on the $16^{\text {th }}$ day $(0.42 \pm$ $0.15 \mu \mathrm{g} / \mathrm{ml})(p<0.001)$.

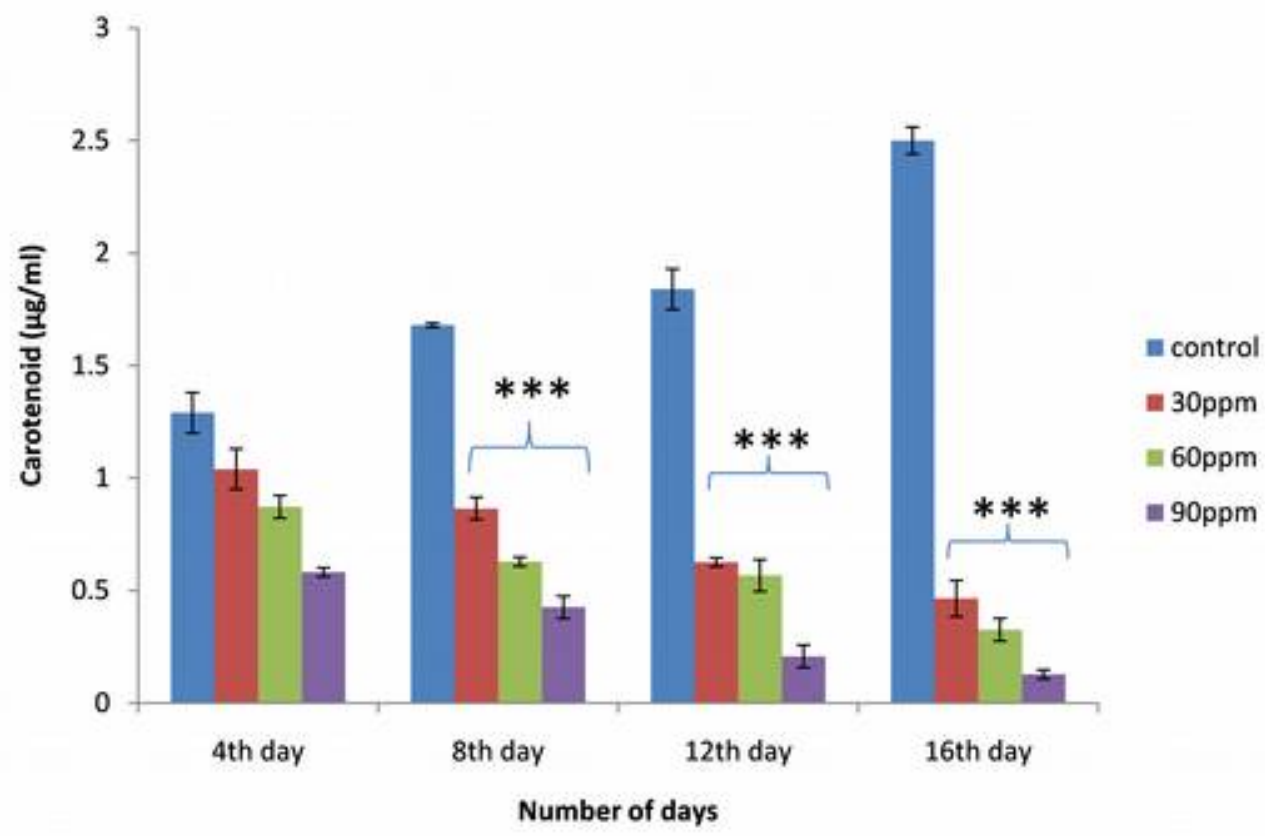

Fig. 3. Effect of different concentrations of malathion on the carotenoid content of $W$. prolifica at different time intervals. The values are presented as mean \pm SD of three replicates. Asterisks $\left({ }^{*} p<0.05,{ }^{* *} p<0.01,{ }^{* * *} p<0.001\right)$ above the histogram bars depicts significant variation in the pesticides treated samples over the control.

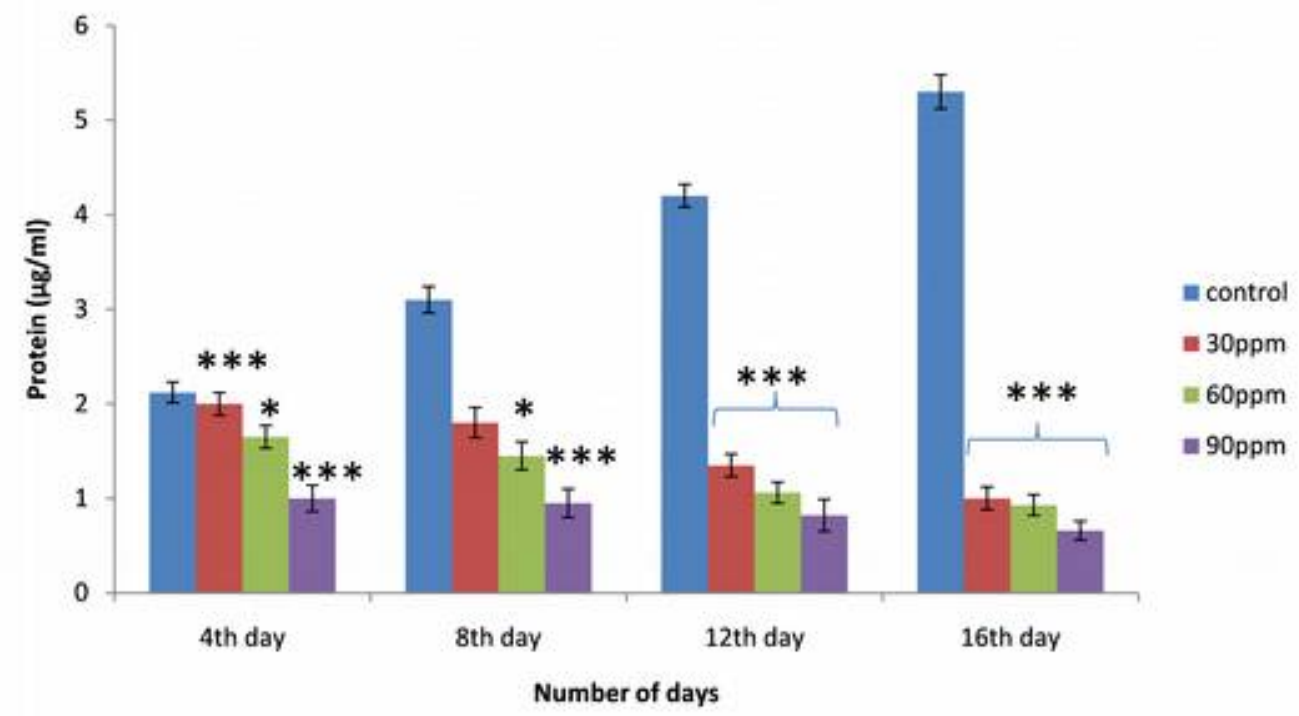

Fig. 4. Effect of different concentrations of malathion on the protein content of $W$. prolifica at different time intervals. The values are presented as mean $\pm \mathrm{SD}$ of three replicates. Asterisks $\left({ }^{*} p<0.05,{ }^{* *} p<0.01,{ }^{* * *} p<0.001\right)$ above the histogram bars depicts significant variation in the pesticides treated samples over the control. 


\section{Carotenoid}

Results obtained after exposing the test organism to different concentrations of malathion is presented in Fig. 3. A remarkable degree of Carotenoid inhibition was observed in $W$. prolifica after exposure to malathion treatment for a period of 16 days. Carotenoid content of the test species was observed to be affected by the pesticide in a time dose dependent manner. In the control sets, an exponential growth was observed up to the $16^{\text {th }}$ day from the day of inoculation throughout the experiment period. The highest carotenoid content was observed in the control during the $16^{\text {th }}$ day $(2.5 \pm 0.06 \mu \mathrm{g} / \mathrm{ml})$ and lowest reduction was observed on the $16^{\text {th }}$ day $(0.12 \mathrm{i} 88 \mathrm{z} \pm 0.02 \mu \mathrm{g} / \mathrm{ml})$ at 90ppm $(p<0.001)$.

\section{Protein}

The effect on the protein content of the test species with malathion treatment is shown in Fig. 4. There was a gradual reduction in the protein content with increase in pesticide concentration in a time and dose dependent manner. The highest protein content was found in the control sets $(5.3 \pm 0.18) \mu \mathrm{g} /$ $\mathrm{ml}$ and lowest at $90 \mathrm{ppm}(0.66 \pm 0.1) \mu \mathrm{g} / \mathrm{ml}$ on the $16^{\text {th }}$ day $(p<0.001)$.

\section{Carbohydrate}

Results of carbohydrate content obtained after exposing the test organism to varying malathion concentrations is depicted in the Fig. 5. The carbohydrate content was found to be decreasing gradually from lower to higher pesticide concentration with increase in time period. There was a significant reduction in carbohydrate content at $90 \mathrm{ppm}$ on $12^{\text {th }}$ day $(p<0.001)$ concentration and on $16^{\text {th }}$ day $(p<0.001)$ from the day of inoculation.

\section{Discussion}

The effect of Malathion on the biomass of $W$. prolifica as observed in Fig. 1 shows that it has a significant effect on the growth of the species. The pesticide showed deleterious effect on the biomass content of the test species. The biomass decreases considerably with the increase in concentration of the pesticide with time. On the other hand, in the control sets, a steady growth was observed up to the $16^{\text {th }}$ day from the day of inoculation. The decrease in biomass might be due to the inhibition of photosynthesis by the application of the pesticide (22). This observation supports previous findings on Anabaena variabilis exposed to malathion pesticide (23). However, an insignificant increase in biomass at $30 \mathrm{ppm}$ on $4^{\text {th }}$ day might be an adaptive measure adopted by the test organism at low pesticide concentration (17).

Malathion treatment in $W$. prolifica affects its chlorophyll-a content in different blue green algae by taking part in light absorption and photochemistry (25). The chlorophyll-a content of the species after treatment with the pesticide was seen to be enhanced at low concentration of pesticide i.e. at $30 \mathrm{ppm}$ and there was an increase in the pigment up to the $8^{\text {th }}$ day from the day of inoculation compared to the control (Fig. 2). With gradual increase in the concentration of the pesticide with time, the content of chlorophyll-a decreased. This is an indication that photosynthesis is inhibited at higher pesticide

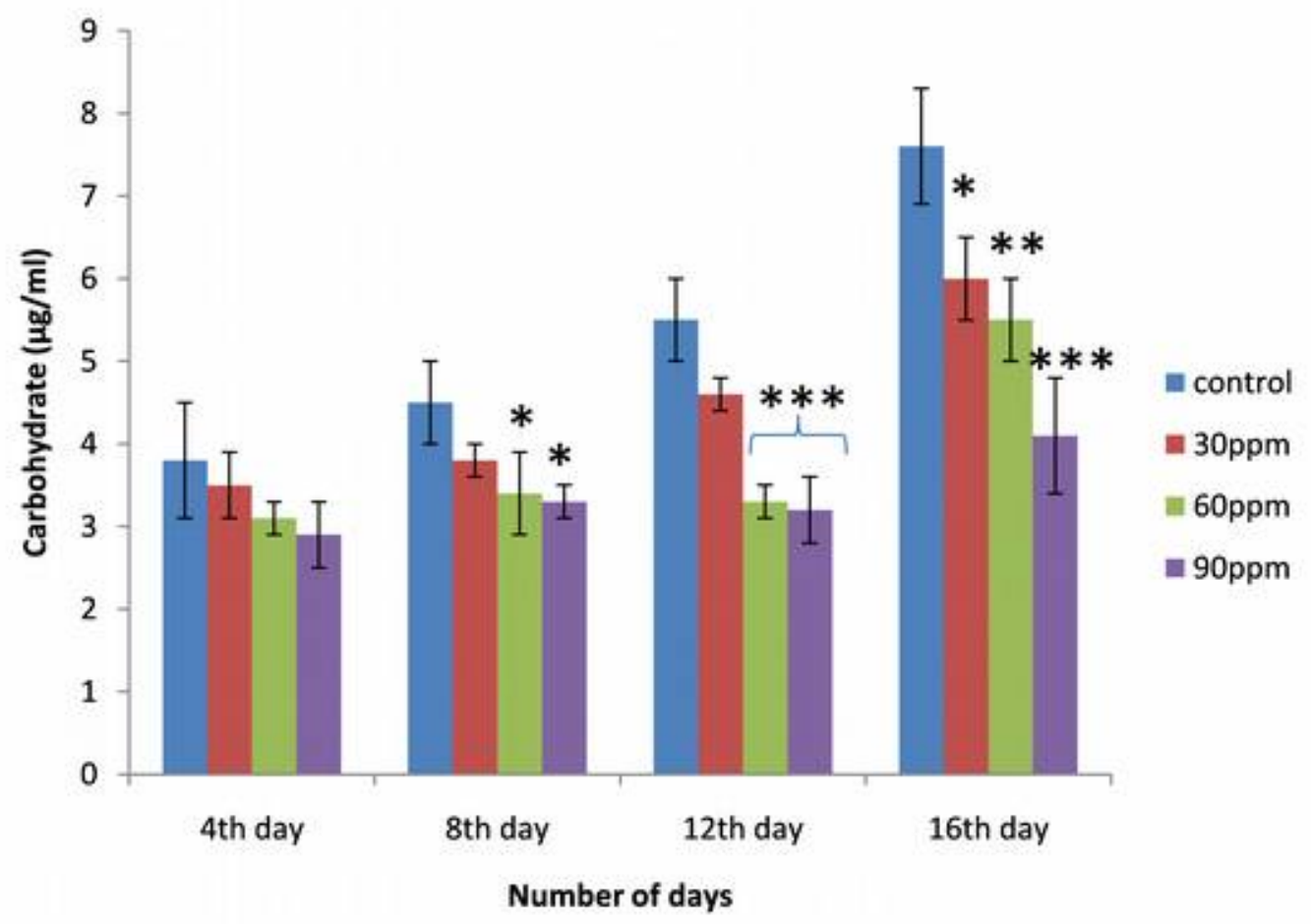

Fig. 5. Effect of different concentrations of malathion on the carbohydrate content of $W$. prolifica at different time intervals . The values are presented as mean $\pm \mathrm{SD}$ of three replicates. Asterisks $\left({ }^{*} p<0.05,{ }^{* *} p<0.01,{ }^{* * *} p<0.001\right)$ above the histogram bars depicts significant variation in the pesticides treated samples over the control. 
concentration (4). The inhibition of photosynthesis accelerates degradation rate of pigments to meet the energy demands of the cells by producing carbon skeleton in the cell (26). Similar to our findings, other studies also reported that the effect of malathion on cyanobacterial and algal populations has stimulatory effect at lower concentration (30ppm) and inhibitory at higher concentration $(90 \mathrm{ppm})$ of the pesticide $(27,28)$.

Carotenoid which is an accessory pigment of cyanobacteria plays an important protective role in photo-oxidative damage and also serves as light harvesting pigment during photosynthesis (29). The carotenoid pigment which is associated with the photosynthetic process was seen to be decreasing with increase in pesticide concentrations and time throughout the study (Fig. 3 ). The decrease in carotenoid content specifies that the pesticide not only accelerated the degradation process but also blocked their synthesis (30). This result is in consonance with another study where the authors observed similar effect of carotenoid content in Anabaena cylindrica with molinate (24).

Protein is an important metabolite in cyanobacteria. The data obtained, highlights gradual decrease in protein content with increase in pesticide dose with time (Fig. 4). This decrease in protein content with increase in time could be due to the inhibition in the synthesis of enzymes and structural proteins which are necessary for the growth of cyanobacteria (30). This result is in agreement with previous reports $(4,31)$.

It was recorded that increase in concentration of pesticide drastically retarded the carbohydrate content of $W$. prolifica (Fig. 5), and it could be possibly due to the conversion of sugars into other metabolites (32). This observation supports a previous study (33) where authors observed reduction in carbohydrate content of Anabaena fertilissima, Aulosira fertilissima and $W$. prolifica with increase in Endosulfan and Tebuconazole pesticides. On the $16^{\text {th }}$ day, though carbohydrate content decreased as compared to the control but the value was observed to be higher than that of the values recorded for $4^{\text {th }}, 8^{\text {th }}$ and $12^{\text {th }}$ days of incubation periods at 30,60 and $90 \mathrm{ppm}$ of the concentrations of the pesticides. It could be attributed to the decrease in protein synthesis leading to accumulation of carbohydrate and lipids inside the cells (34) and the results were in concomitant with previous findings (35) on Anabaena variabilis treated with malathion.

\section{Conclusion}

From the results obtained after evaluating the effects of malathion on the growth parameters of $W$. prolifica, it was observed that malathion has adverse effect on all the tested parameters of the test organism. A lower concentration of malathion for a short time of exposure though caused enhancement of the biomass and chlorophyll-a in $W$. prolifica but the increase was not significant over the control. With gradual increase in pesticide concentration with time there was an overall reduction in the tested parameters. Considering the adverse affect on the natural biofertilizer like $W$. prolifica, it is suggested to restrict the use of malathion in the rice field ecosystems.

\section{Author's contributions}

Both the authors participated in the design, planning, and implementation of the study and were also instrumental in the writing of the manuscript.

\section{Conflict of interest}

The authors declare that they have no conflict of interests.

\section{Acknowledgments}

The authors are grateful to the Head, Department of Botany, Gauhati University, Assam, India, for providing laboratory facilities developed under DST-FIST, UGC -SAP programme and MoEF \& CC to carry out the research work. The first author is also thankful to Dr. Tridip Phukan of Gauhati University for his support in undertaking the statistical analysis.

\section{References}

1. Ware GW. Pesticides: theory and application. Freeman, Newyork. 1983.

2. Maly M, Rubber E. Bull. Environ. Contam. Toxicol. 1983; 30:464. https://doi.org/10.1007/BF01610161

3. Bambaradeniya CNB, Amerasinghe FP. Biodiversity Associated with the Rice Field Agroecosystem in Asian Countries: A Brief Review. Colombo, Sri Lanka: International Water Management Institute Working Paper. 2003. p.63.

4. Singh DP, Khattar JIS, Guota M, Kaur G. Evaluation of toxicological impact of cartap hydrochloride on some physiological activities of a non-heterocystous cyanobacterium Leptolyngbya foveolarum. Pestic $\begin{array}{lll}\text { Biochem } & \text { Physiol. } & \text { 2014;110.63-70. }\end{array}$ https://doi.org/10.1016/j.pestbp.2014.03.002

5. Patil VK, David M . Behaviour and respiratory dysfunction as an index of Malathion toxicity in the freshwater fish", Labeo rohita (Hamilton)", Turk J Fish Aqua Sci. 2008; 8:233.

6. Anton FA, Laborda E, Laborda P, Ramos E. Carbofuran acute toxicity to freshwater algae and fish. Bull Environ $\begin{array}{llll}\text { Contam } & \text { Toxicol. 1993; } & \text { 50: } 400 .\end{array}$ https://doi.org/10.1007/BF00197199

7. Tiwari O, Prasanna R, Yadav A, Dhar WD , Singh P. Growth potential and biocide tolerance of nonheterocystous filamentous cyanobacterial isolates from 
rice fields of Uttar Pradesh. India,Biol Fertil Soils. 2001; 34: 291. https://doi.org/10.1007/s003740100402

8. Singh DP, Khattar JIS, Kaur M, Kaur G, Gupta M, Singh Y. Anilofostoleranceand its mineralization by the cyanobacterium Synechocystis sp. strain PUPCCC 64.PLoS ONE. 2013; $\quad$ 8: https://doi.org/10.1371/journal.pone.0053445

9. Venkataraman GS. Blue green algae: a possible remedy to nitrogen scarcity. Curr Sci. 1981; 50:253-56.

10. Nayak S, Prasanna R. Soil pH and its role in cyanobacterial abundance and diversity in rice field soils. Appl Ecol Environ Res. 2007; 5: 103-13. https://doi.org/10.15666/aeer/0502 103113

11. Singh OA, Tiwari GO. Part 3: An account of heterocystous stigonematalean cyanobacterial biodiversity of North East Region of India. J. Indian bot. Soc. 2011; 90(3\&4): 200-06.

12. Singh RN. The role of Blue Green Algae in Nitrogen economy of Indian agriculture. Indian Council of Agricultural Research and Publication. New Delhi. 1961.

13. Irisarri $\mathrm{P}$, Gonnet $\mathrm{S}$, Monza J. Cyanobacteria in Uruguayan rice fields: Diversity, nitrogen fixing ability and tolerance to herbicides and combined nitrogen. J. Biotechnol. 2001; 91: 95-103. https://doi.org/10.1016/S0168-1656(01)00334-0

14. Singh NK, Dhar DW. Cyanobacterial reclamation of saltaffected soil. In: Genetic engineering, biofertilisation, soil quality and organic farming (Ed. by E. Lichtfouse). Springer Science p Business Media B.V., Dordrecht, the Netherlands.2010; 243-75. https://doi.org/10.1007/978-90481-8741-6 9

15. Pankratz FB, Doebel C, Farenhorst A, Goldborough LG. Interaction between algae (Selenastrum capricornutum) and pesticides. Implication for managing constructed wetlands for pesticides removal. J Env Sci Health B. 2003;38:147-55. https://doi.org/10.1081/PFC-120018445

16. Kumar NJI, Khusboo B, Rita K, Jeegna B. Biochemical and enzymatic investigation of Westiellopsis prolifica Janet in response to mercury stress.Int J Adv Res. 2015; 3(7): 1018-29.

17. Gupta K, Baruah PP. Effect of lambdacyhalothrin on Calothrix sp. (GUEco 1001), an authchthonous cyanobacterium of rice fields of Brahmaputra floodplain. Environ Sci Pollut Res.2015; 22:18554-60. https://doi.org/10.1007/s11356-015-5181-4

18. Mackinney G. Absorption of light by chlorophyll solution. J Biol Chem.1941;140:315-22.

19. Myers J, Kratz WA. Relationship between pigments content and photosynthetic characteristics in a blue green algae. J Gen Physiol. 1955; 39:11-21. https://doi.org/ 10.1085/igp.39.1.11

20. Lowry OH, Rosenbrough NH, Farr AL, and Randall RJ. Protein measurements with folinphenol reagent. J Biol Chem. 1951; 193: 265-75.

21. Spiro RG. Analysis of sugars found in glycoprotein. Methods in Enzymol. 1966; 8:3-26. https://doi.org/10.1016/0076-6879(66)08005-4

22. Prosperi $\mathrm{C}$, Luna $\mathrm{C}$, Valiente EF. Influence of $\mathrm{pH}$ light intensity and oxygen on the short term effect of ammonium on nitrogenase activity of cyanobacteria from rice fields. Environ Exp. 1993; 33(4): 545-52. https:// doi.org/10.1016/0098-8472(93)90029-F
23. Ningthoujam $M$, Satyendra $K$, Khalid $H$, Tasneem $F$. Biochemical Analysis of Anabaena variabilis Exposed to Malathion Pesticide with Special Reference to Oxidative Stress and Osmolytes. International Journal of Innovative Research in Science, Engineering and Technology. 2003;2(10):5403-20.

24. Galhano V, Peixoto F, Gomes-Laranjo J, FernandezValiente E. Differential effect of bentazon and molinate on Anabaena cylindrica, an autochthonous cyanobacterium of Portuguese rice field agro ecosystem. Water Air Soil Pollut. 2009; 197(1-4):211-22. https://doi.org/10.1007/s11270-008-9804-y

25. Eullaffroy P, Vernet G. The F684/F735 chlorophyll fluorescence ratio: a potential tool for rapid detection and determination of herbicide phytotoxicity in algae.Water Res. 2003;37(9):1983-90. https://doi.org/10.1016/S0043-1354(02)00621-8

26. Mohapatra PK, Patra S, Samantaray PK, Mohanty RC . Effect of the pyrethroid insecticide cypermethrin on photosynthetic pigments of the Cyanobacterium Anabaena doliolum Bhar. Pol. J. Environ. Stud. 2003;12: 207-12.

27. Tandon RS, Lal R, Rao N, VVS. Interaction of endosulfan and malathion with blue-green algae Anabaena and Aulosira fertilissima. Environ Poll. 1988; 52: 1-9. https://doi.org/10.1016/0269-7491(88)90103-0

28. Yamamoto Y, Tsukada H. Measurement of in situ specific growth rates of microcystis (cyanobacteria) from the frequency of dividing cells. J Phy. 2009; 45: 1003-09. https://doi.org/10.1111/j.1529-8817.2009.00723.x

29. Schagerl M, Muller B. Acclimation of chlorophyll a and carotenoid levels to different irradiances in four freshwater cyanobacteria. J Plant Physiol. 2006;163: 70916. https://doi.org/10.1016/j.jplph.2005.09.015

30. Kapoor K, Leenta A . Observations on growth responses of cyanobacteria under the influence of herbicides. Poll Res. 1996; 15(4): 343-51.

31. Dowidar SMA, Osman MEH, Naggar AHEI, Khalefa AE. Effect of butachlor and thiobencarb herbicides on protein content and profile and some enzyme activities of Nostoc muscorum. J Genet Eng Biotechnol. 2010; 8:8995.

32. Chai JK, Chung YS. Physiological effects of 2,4dichlorophenoxyacetic acid (2,4-D) on Chlorella ellipsoidea. MisaengmulHakhoe Chi. (in Korean). 1975; 13:101-08.

33. Kumar N, Bora A, Kumar R, Kaur M. Differential Effects of Agricultural Pesticides Endosulfan and Tebuconazole on Photosynthetic pigments, Metabolism and Assimilating Enzymes of Three Heterotrophic, Filamentous Cyanobacteria. J. Biol. Environ. Sci. 2012; 6(16): $67-75$.

34. Averamova S, Rossler M .Effect of various temperatures on some physiological-biochemical induces during the light phase of the life cycle of Scenedesmus sp. Appl Microbiol. 1975; 5: 115-20.

35. Manikar N, Kumar S, Habib K. and Fatma T. Biochemical analysis of Anabaena variabilis exposed to malathion pesticide with special references to oxidative stress and osmolyte. Int J Innov Res Sci Eng Technol. 2013; 2:540320. 